\title{
Preliminary Calibration of Stalagmite 0xygen Isotopes from Eastern Monsoon China with Northern Hemisphere Temperatures
}

Ming Tan and Binggui CaI

Institute of Geology and Geophysics, Chinese Academy of Sciences, Beijing 100029, China; tanming@mail.iggcas.ac.cn

Changes in stalagmite oxygen isotope ratios that are related to the India Monsoon during the Holocene have been widely discussed (e.g., Neff et al., 2001, Fleitmann et al., 2003). The number of stalagmite oxygen isotope series from the Holocene in China that have been reported is limited but increasing (Hou et al., 2003, Zhang et al., 2003, 2004, Wang et al., 2005). However, the relationships between the oxygen isotope ratios of stalagmites from northeastern and southeastern China have not been discussed. In this preliminary report, we compare the stalagmite oxygen isotope records from the Eastern Monsoon China (East of $108^{\circ} \mathrm{E}$ ), and focus on two questions:

1. What is the range in values and the time series pattern for stalagmite oxygen isotope ratios from Eastern Monsoon China?

2. What is the signature represented by the change in stalagmite oxygen isotope records from Eastern Monsoon China within the entire Holocene?

\section{Data and Methods}

Here, we present and compare four stalagmite oxygen isotope records from Water Cave (unpublished), Shihua Cave (Hou et al., 2003), Dongge Cave (Wang et al., 2005) and Xiangshui Cave (Zhang

Table 1: Sample-specific details

\begin{tabular}{|c|c|c|c|c|}
\hline Cave location & $\begin{array}{l}\text { Latitude and } \\
\text { longitude }\end{array}$ & $\begin{array}{l}\text { Oxygen isotope } \\
\text { ratio range (per } \\
\text { mill PDB) }\end{array}$ & $\begin{array}{l}\text { Time interval } \\
\text { covered }\end{array}$ & $\begin{array}{l}\text { Availability of } \\
\text { data }\end{array}$ \\
\hline $\begin{array}{l}\text { Water Cave: } \\
\text { Benxi, Liaoning } \\
\text { Province }\end{array}$ & $\begin{array}{l}41^{\circ} 17^{\prime} \mathrm{N} \\
124^{\circ} 04^{\prime} \mathrm{E}\end{array}$ & -8.2 to -9.5 & $\begin{array}{l}\text { About } 5000 \text { years } \\
\text { (from about } 3000 \\
\mathrm{BC} \text { to } 300 \text { years } \\
\text { before present) }\end{array}$ & unpublished \\
\hline $\begin{array}{l}\text { Shihua Cave: } \\
\text { Beijing }\end{array}$ & $\begin{array}{l}39^{\circ} 47^{\prime} \mathrm{N}, \\
115^{\circ} 56^{\prime} \mathrm{E}\end{array}$ & -7.5 to -9.1 & $\begin{array}{l}\text { About } 2200 \text { years } \\
\text { (from about } \\
200 \mathrm{BC} \text { to present) }\end{array}$ & Tan et al., 2003 \\
\hline $\begin{array}{l}\text { Dongge Cave: } \\
\text { Libo, Guizhou } \\
\text { Province }\end{array}$ & $\begin{array}{l}25^{\circ} 17 \text { 'N, } \\
108^{\circ} 05^{\prime} \mathrm{E}\end{array}$ & -6.64 to -9.14 & $\begin{array}{l}\text { About } 9000 \text { years } \\
\text { (from } 6930 B C \text { to } \\
2000 A D \text { ) }\end{array}$ & Wang et al., 2005 \\
\hline $\begin{array}{l}\text { Xiang shui Cave: } \\
\text { Guanyang, } \\
\text { Guangxi Province }\end{array}$ & $\begin{array}{l}25^{\circ} 15^{\prime} \mathrm{N}, \\
110^{\circ} 55^{\prime} \mathrm{E}\end{array}$ & -5.6 to -6.5 & $\begin{array}{l}\text { About } 6000 \text { years } \\
\text { (from about } \\
4000 \mathrm{BC} \text { to } 500 \\
\text { years ago) }\end{array}$ & Zhang et al., 2004 \\
\hline
\end{tabular}

et al., 2003, 2004), respectively (see Table 1 for details).

The timescale of the stalagmite from Water Cave was derived by fitting the uranium dates $(511 \pm 80$, $2081 \pm 73,3845 \pm 45,5227 \pm 83$ years before AD 2000) with the distance of the dated site $(2.09,49.63$, $96.96,157.23 \mathrm{~mm}$ ) from the top of the stalagmite. The fit function is:

$Y=-0.0011 X^{3}+0.2155 X^{2}+$ $24.829 X+458.22$ (where $Y$ is age, $X$ distance from the top; $r^{2}=1$ ).

For the stalagmite from Shihua Cave, we used counting chronology to recalibrate the oxygen isotope time series. Since the age

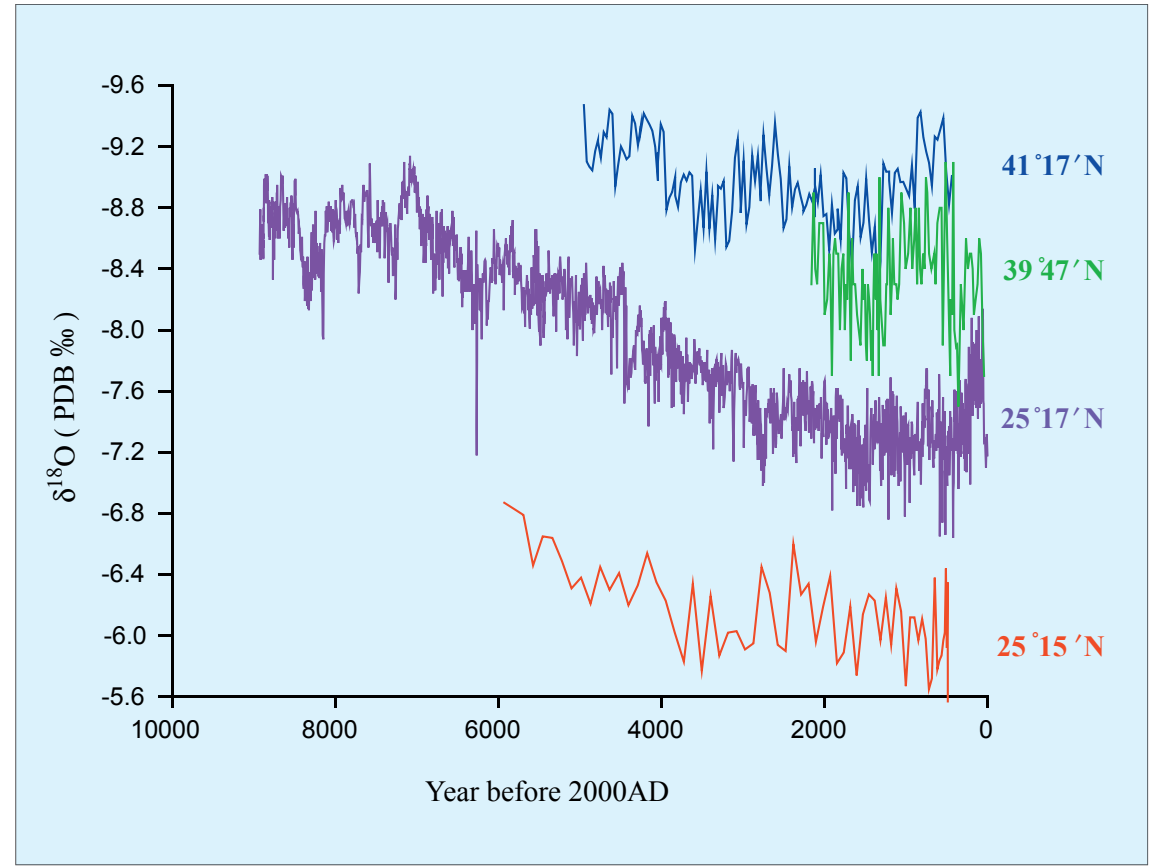

Fig. 1: Comparison of stalagmite oxygen isotope record from Water Cave (blue) with that from Shihua Cave (green), Dongge Cave (purple) and Xiangshui Cave (red).

of the top layer is known, we can measure the distance of each isotope sub-sample site from the top and calculate an age by summing annual layer thicknesses to match the distance measured. Finally, we can accurately use the layers counted as the age of each site.

For the stalagmite from Xiangshui Cave, we recalibrated the timescale for the oxygen isotope series by fitting the four uranium dates to the distances of each sample site dated from the top, based on data in Zhang et al. $(2003,2004)$. The fit function is:

$Y=-0.0095 X^{3}+1.8735 X^{2}+$ $5.1317 X+489.89$ (where $Y$ is age, $X$ distance from the top; $r^{2}=1$ ).

The four stalagmite oxygen isotope records are compared in Figure 1.

\section{Results}

As shown in Figure 1, the oxygen isotope ratios become lighter from south to north. This pattern matches the observed pattern of the summer monsoon. Starting from the South China Sea and going northward, the summer 


\section{Science Highlights: China}

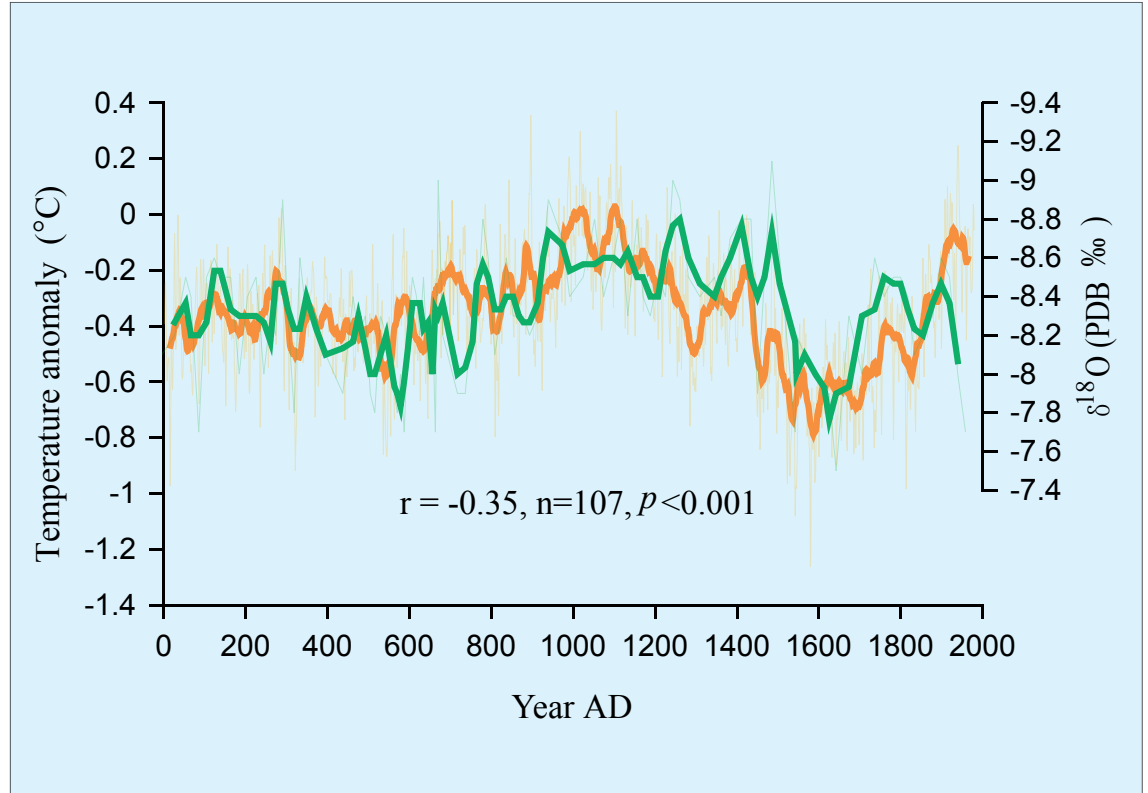

Fig. 2: Oxygen isotope of the stalagmite from Beijing Shihua Cave (green, thick line: 3-point running mean) and the northern hemisphere temperature over the last 2,000 years (yellow, thick line: 31-year running mean, Moberg et al., 2005).

monsoon supplies rainfall from the south to the north, and oxygen isotope ratios become lighter with precipitation. Our comparison of oxygen isotope ratios reveals that in Eastern China, stalagmite oxygen isotope records show similar fluctuation patterns on centennialto-millennial scales. All of them contain a multi-millennial trend towards heaver ratios since $9000 \mathrm{Yr}$ $\mathrm{BP}$, responding to a reduced insolation of the Northern Hemisphere (Berger, 1978, 1991). This suggests that the change in patterns recorded in these ratios in Eastern China results from a single water source (i.e., the summer monsoon just travels northward from the South China Sea, isotopic ratios become lighter, and there is no, or limited, mixing with water with a different oxygen isotopic signature).

To understand what these oxygen isotope time series datasets represent, we compared the record from Shihua Cave, which has ready been age-controlled by counting chronology, to regionaland large-scale quantitatively reconstructed annual proxy records (e.g., Tan et al., 2003; Mann et al., 2003; Moberg et al., 2005). Data is available at: http://wdc.cricyt. edu.ar/paleo/data.html). We find that our re-dated oxygen isotope series has a statistically significant relationship $(r=-0.35, n=107$, $\mathrm{p}<0.001$ ) with the recently reported 2,000-year-long Northern Hemisphere temperature series developed by Moberg et al. (2005). This indicates that the lighter oxygen isotope ratios in the stalagmite from Beijing Shihua Cave correspond to higher temperatures (Fig. 2). Based on this comparison, the stalagmite oxygen isotope ratios from Eastern Monsoon China may be responding to large-scale temperature changes. What should be mentioned is that the stalagmite from Beijing Shihua Cave and its isotope and layer thickness data used here are independent and different (i.e., unique) from another stalagmite from the same cave (Tan et al., 2003) that is included in the Moberg et al. series. Therefore, the relationship shown in Figure 2 is not a circular argument.

\section{Conclusion and Discussion}

It is difficult to obtain long temperature proxy records with anrings, stalagmite layers, etc. The calibration of the oxygen isotope ratios of cave deposits with millennial-long annually resolved temperature records has great potential to semi-quantitatively establish long-term temperature records (e.g. oxygen isotope based themperature reconstrucnual resolution, such as from tree tions of the Northern Hemisphere for the entire Holocene).

The oxygen isotope records from stalagmites before and within the Holocene in Eastern Monsoon China have been interpreted as a signature of the strength of the East Asia Summer Monsoon (Wang et al., 2001, Yuan et al., 2004, Wang et al., 2005). Do our findings contradict this interpretation? No. In fact, the observed temperature record of Beijing has a statistically significant relation (-0.33 from AD 1881 to 1995) with the East Asia Summer Monsoon Index (Shi et al., 1998. Here, the lower the index, the stronger the East Asia Summer Monsoon).

\section{REFERENCES}

Fleitmann, D., Burns, S.J., Mudelsee, M., Neff, U., Kramers, J., Mangini, A. and Matter, A., 2003: Holocene Forcing of the Indian Monsoon Recorded in a Stalagmite from Southern Oman. Science, 30: 1737-1739.

Hou, J.Z., Tan, M., Cheng, H. and Liu ,T.S., 2003: Stable isotope records of plant cover change and monsoon variation in the past 2200 years: evidence from laminated stalagmites in Beijing China, Boreas, 32, 304-313.

Shi Neng, Yang Yongsheng. 1998: Main characteristics of East Asian Summer/Winter Monsoon intensity index for 1873 1996. Journal of Nanjing Institute of Meteorology, 21: 208-213 (in Chinese)

Tan, M., Liu, T., Hou, J., Oin, X., Zhang, H. and Li T. 2003: Cyclic rapid warming on centennial-scale revealed by a 2650-year stalagmite record of warm season temperature, Geophysical Research Letters, 30: 1617-1620.

Wang, Y., Cheng, H., Edwards, R. L. et al. 2001: A high-resolution absolute-dated Late Pleistocene monsoon record from Hulu Cave, China. Science, 294: 2345-2348.

Zhang, M., Yuan, D., Lin, Y., Oin, J., Li, B., Cheng, H. and Edwards, R. L., 2004: A 6000-year high-resolution climatic record from a stalagmite in Xiangshui Cave, Guilin, China. The Holocene, 14: 697-702.

For full references please consult: www.pages-igbp.org/products/newsletters/ref2005_2.html 